\title{
ANÁLISE DO PERFIL DOS APRENDIZES E SERVIDORES DA ESCOLA DE ARTÍFICES DE NATAL (1909-1937)
}

R. M. B. SANTOS e J.L.G. SILVA

Instituto Federal de Educação, Ciência e Tecnologia do Rio Grande do Norte renato.marinho@ifrn.edu.br

Artigo submetido em 23/03/2018 e aceito em 17/12/2019

DOI: $10.15628 /$ holos.2020.7127

\section{RESUMO}

A análise do perfil de discentes e servidores que compuseram a Escola de Aprendizes e Artífices em Natal, entre os anos de 1909 e 1937, é parte de uma pesquisa mais ampla, realizada em programa de doutoramento, que foi desenvolvida a partir de projetos de pesquisa contemplados com bolsa pelo Instituto Federal do Rio Grande do Norte, campus São Gonçalo do Amarante. Tem como objetivo construir um perfil socioeconômico dos aprendizes que ingressaram na Escola no referido período, de modo a entender, entre outros aspectos, as razões para um elevado índice de evasão na instituição, bem como os mecanismos de disciplina usados no espaço escolar. Já em relação aos servidores, objetivou-se saber, entre outras questões, se havia um perfil específico desejado para esses profissionais, bem como se fatores políticos eram considerados para sua nomeação. Em busca das respostas aos questionamentos propostos, exploramos, entre outras fontes, livros de matrícula, diários de classe e termos de posse. Com isso conseguiu-se mapear mais de 1.400 registros de alunos e mais de 60 servidores, durante o período pesquisado.

PALAVRAS-CHAVE: Ensino Industrial, Disciplina, Aprendizes, Servidores.

\section{PROFILE ANALYSIS OF APPRENTICE AND SERVERS OF THE SCHOOL OF ARTIFICERS OF NATAL}

\begin{abstract}
The analysis of the profile of students and servants who composed the School of Apprentice and Craft in Natal, between the years 1909 and 1937, is part of a broader research carried out in a doctoral program that was developed from research projects awarded with scholarship by the Federal Institute of Rio Grande do Norte, campus São Gonçalo do Amarante. The objective is to construct the socioeconomic profile of apprentices, in order to understand, among other aspects, the reasons for a high dropout rate in the School, as well as
\end{abstract}

the mechanisms of discipline used in school space. Regarding the servers, the objective was to know, among other questions, if there was a specific profile desired for these professionals, as well as whether political factors were considered for their appointment. In search of the answers to the proposed questions, we explore, among other sources, books of registration, class journals and terms of possession. As a result, it was possible to map more than 1.400 student records and more than 60 servers during the period studied.

KEYWORDS: Industrial Education, Discipline, Apprentices, Servers. 


\section{INTRODUÇÃO}

A fundação das Escolas de Aprendizes Artífices, pelo então Presidente da República, Nilo Peçanha, através do Decreto n. 7.566, inicia o processo de implantação e disseminação do ensino profissional, de âmbito federal, no Brasil. Dezoito Escolas de nível primário foram criadas ${ }^{1}$, por todo o território nacional, com o objetivo de fornecer educação profissionalizante àqueles que eram, à época, vistos pelos dirigentes republicanos como tendenciosos aos maus costumes. No preâmbulo do referido Decreto, tal objetivo é explicitado:

[Cabe às Escolas de Aprendizes] formar operários e contra-mestres, ministrando-se o ensino prático e os conhecimentos technicos necessários aos menores que pretenderem aprender um officio, havendo para isso ate o numero de cinco officinas de trabalho manual ou mecânico que forem mais convenientes e necessárias no Estado em que funccionar a escola, consultadas quando possível, as especialidades das industrias locaes. (BRASIL, 1909)

Além da formação profissional, havia a preocupação, por parte dos dirigentes da República, com uma formação moral. Como nos explica o historiador Sidney Chalhoub, a partir da Lei Áurea, milhares de homens que antes viviam no regime da escravidão tornaram-se libertos, sem terem, na visão dos que dirigiam os destinos do país, condições de viverem harmonicamente em sociedade. Isso porque, de acordo com essa visão, "a escravidão não havia dado a esses homens nenhuma noção de justiça, de respeito à propriedade, de liberdade" (Chalhoub, 2001, p. 68), o que poderia facilmente levar esses homens tidos pelos que comandavam o Império brasileiro como incivilizados e propensos ao mundo da vadiagem, dos vícios e dos crimes. Daí serem constantes nos relatórios do Ministério da Agricultura, Indústria e Comércio a referência a essa formação moral, como se vê na fala do ministro João Pereira Lima, em relatório referente ao ano de 1918: "ponham-se aos olhos da criança hábitos constantes de disciplina, de ordem, de obediência, de polidez e de bondade, e quase toda a obra considerar-se-á feita" (LIMA, s.d., p. 140).

É certo que por parte dos aprendizes houve, em ocasiões diversas, resistência a essa disciplina que se desejava incutir-lhes. Além disso, as questões materiais - os aprendizes, de origem humilde, precisavam muitas vezes contribuir para o sustento da família - também levaram a Escola a ter, durante todo o período estudado, elevado índice de evasão, aspecto a ser também analisado neste artigo.

Diante do que foi dito, o objetivo desta pesquisa é compreender quem foram os sujeitos históricos que fizeram parte da Escola de Aprendizes Artífices, seja na condição de alunos das suas

\footnotetext{
${ }^{1}$ Além destas, o Instituto Parobé, fundado em 1906 na cidade de Porto Alegre-RS, foi subvencionado pelo governo federal ao longo do período estudado, compondo, juntamente com as Escolas de Aprendizes, a rede de ensino profissional voltado para a indústria no Brasil.
} 
oficinas, seja na de servidores, tendo em vista que uma melhor compreensão do funcionamento dessa instituição e de que ensino era ali ministrado passa, também, pela análise do perfil dos profissionais que a compunham.

Livros de matrícula, termos de posse, relatórios e legislação estão entre as principais fontes a serem analisadas. Para além das normas presentes em alguns desses documentos, desejamos saber: no chão da Escola, em seu cotidiano, quem cuidou para que as regras estabelecidas em leis fossem cumpridas? Quem foram esses personagens e como agiram? O que podemos falar sobre os aprendizes? Como reagiam ao que lhes era imposto? É possível defini-los apenas como desfavorecidos de fortuna?

\section{REVISÃO BIBLIOGRÁFICA}

Para melhor compreensão do tema, bem como para se ter uma melhor visão acerca da realidade vivenciada no período abordado na pesquisa, foram utilizadas diversas produções no campo da História da educação profissional. Estas obras auxiliam o desenvolvimento do trabalho, mostrando-nos, em diferentes perspectivas, o tema da pesquisa.

Sobre ensino industrial, Fonseca (1986) apresenta uma leitura mais tradicional do tema, de modo a tomar os documentos que se espalham pelo seu texto como fontes de uma verdade que não precisa ser questionada. Fonseca apresenta inúmeros documentos produzidos pelo estado, relevantes ao trabalho, tais como: leis, projetos de leis, decretos, portarias, regimentos, entre outros.

O autor destaca, no primeiro parágrafo de sua obra - História do ensino industrial no Brasil -, que a mesma "não tem veleidades literárias. Narra, apenas, a história do ensino industrial em nosso país, de maneira metódica e estritamente de acordo com a documentação existente." (FONSECA, 1986, p. 7). Apesar de um olhar positivista, a leitura de Fonseca permite-nos uma compreensão macro da formação da educação profissional no Brasil, por adotar um recorte temporal mais alargado, indo do período colonial à Era Vargas, e também pela gama de fontes apresentadas em seu estudo.

Relativamente à compreensão das práticas disciplinares estabelecidas pelas normas da Escola e aplicadas por seus servidores, a obra Vigiar e punir, de Foucault (2009), foi utilizada. O autor entende que a formação do poder disciplinar incide especialmente sobre três espaços: escolar, hospitalar e militar. E mostra as trocas entre tais espaços. $O$ treinamento militar recebido pelos aprendizes em 1913; a adoção da ginástica como disciplina escolar, na década de 1920; e a implantação de um grupo de escotismo, em fins da década de 1930, não representariam, no caso da Escola de Aprendizes de Natal, esse contato, interseção, ou troca de elementos entre o espaço militar e o escolar, que ajudariam a disciplinar aquela massa de homens referidos pelos dirigentes da República como "classe perigosa"?

Esse poder de disciplinar, que surge no século XVIII, estaria ligado a um contexto de crescimento demográfico, aumento da população flutuante e mudança da escala quantitativa dos grupos que importa controlar ou manipular. É certo que as condições apontadas por Foucault como fundamentais para o estabelecimento do poder disciplinar se apresentam, com maior ou menor força, no contexto de criação das Escolas de Aprendizes Artífices nas capitais brasileiras no 
início do século XX. Os grupos que importava controlar e manipular, por exemplo, cresciam consideravelmente com o fim da escravidão no fim do século anterior.

Para um entendimento mais amplo da época tratada na pesquisa, utilizamos Chalhoub (2001), que, em Trabalho, lar e botequim trata, dentre outros aspectos, da transição do trabalho escravo para o livre no Brasil, destacando a preocupação da recém instaurada República brasileira em combater a ociosidade e os vícios que marcavam, nas palavras da elite dirigente, as "classes perigosas", a partir de da construção de uma nova ética do trabalho, a qual é marcante nas Escolas de Aprendizes Artífices inauguradas em 1909 no Brasil. Ressaltamos que a obra de Chalhoub é valiosa para nós também por mostrar as resistências desses grupos populares à disciplina que se Ihes procurava impor.

No campo da História da Educação profissional no Brasil, o livro $O$ ensino de ofícios nos primórdios da industrialização, de Luiz Antônio Cunha (2005), trata das causas que levaram à criação das Escolas de Aprendizes e aborda como seria a escola de acordo com os planos dos que dirigiam a República brasileira, bem como os problemas vivenciados em sua realidade cotidiana.

Numa escala mais local, trabalhos como o de Arilene Medeiros e Francisco Carlos de Sousa, nos possibilitaram uma inserção na história da Escola de Aprendizes de Natal. Ambos os autores trabalham com recorte temporal mais amplo que o nosso. Medeiros, em A forja e a pena, dá voz a muitos dos aprendizes e servidores que fizeram o Liceu Industrial e a Escola Industrial de Natal, a partir da metodologia da História oral e de um variado leque de documentos que permitem um olhar que vai da Escola de Aprendizes ao Cefet (de 1909 até o fim dos anos 1990). Francisco Carlos de Sousa (2015), por sua vez, analisa em sua tese - intitulada Em nome da ordem e do progresso: a formação profissional no percurso da Escola de Aprendizes Artífices à Escola Técnica Federal do Rio Grande do Norte (1909-1971) - a formação profissional dos alunos que passaram pela escola, desde sua primeira fase até os tempos da Escola Técnica Federal (ETFRN).

\section{METODOLOGIA}

O estudo caracteriza-se como quantitativo e qualitativo, por tratar do levantamento de registros e da sua respectiva análise. Inicialmente foi realizado uma pesquisa no estado da arte, para identificar trabalhos que servissem para fundamentar e fornecer embasamento teórico ao estudo.

A outra etapa foi a de inserção dos dados dos servidores presentes nos documentos em um uma planilha do Excel, para uma leitura inicial. Em seguida, as informações foram transportadas para um banco de dados na World Wide Web (WWW).

Sabendo-se da quantidade de dados a serem analisados, o estudo foi dividido em três fases: a primeira consistiu na análise dos aprendizes, devido a quantidade de alunos matriculados, a segunda, na análise dos servidores, e, a terceira, na análise da relação de ambos no ambiente escolar. A Figura 1 apresenta a síntese das etapas citadas. 


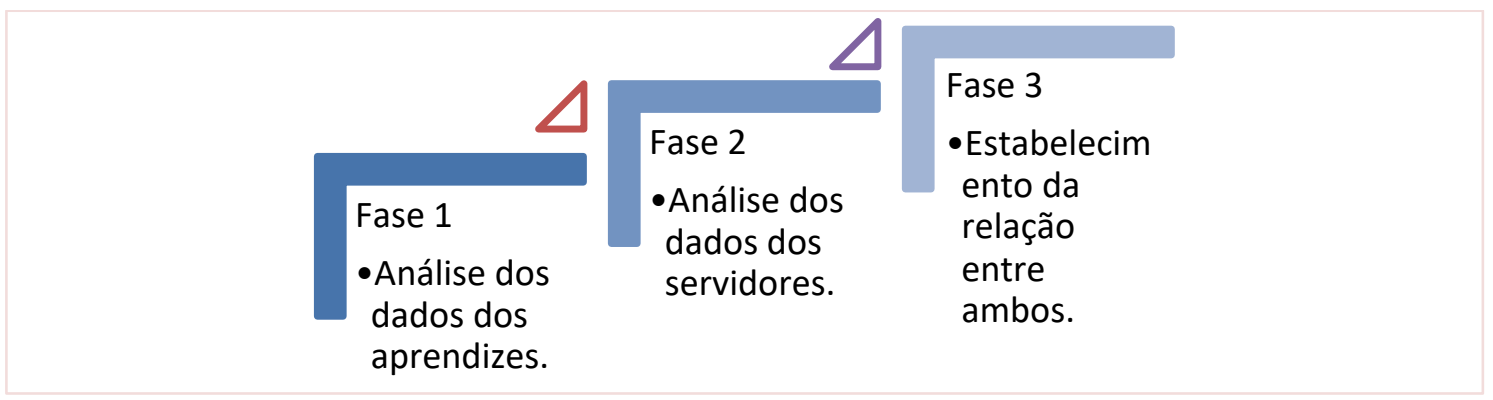

Figura 1 - Etapas das análises de perfis

Fonte: elaboração própria

O projeto toma como base a análise documental, destacando-se entre as fontes pesquisadas, para análise do perfil dos servidores, os termos de posse de funcionários, os livros de assentamento de pessoal, e os relatórios ministeriais; já para os aprendizes utilizou-se, sobretudo, os livros de matricula. Todos os documentos foram produzidos entre 1909 e 1937.

Para traçar um breve perfil dos funcionários da Escola de Natal foram analisadas cinco fontes: os termos de posse (1909-1945) - exposto na Figura 2 -, dois livros de assentamento de pessoal, iniciados nos anos de 1911 e 1912 e fichas funcionais.

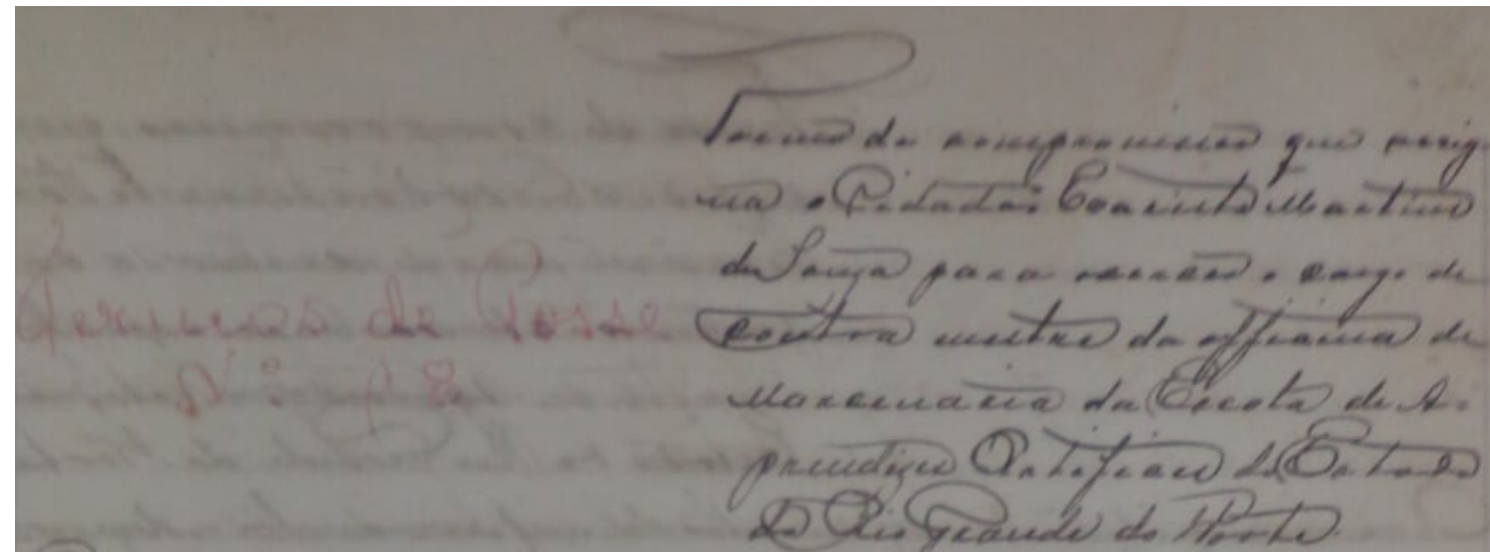

Figura 2 - Termo de posse № 18, datado de 1920, do servidor Evaristo Martins de Souza Fonte: acervo do IFRN

Os dados pertinentes à análise dos servidores foram extraídos, em sua maioria, dos termos de posse, bem como do registro funcional dos servidores. As informações levantadas tratam do nome, data de nascimento e idade, estado civil, gênero, cargo/função, data de entrada e saída, seu respectivo histórico dentro e fora da instituição.

A Figura 3 traz um trecho de página e revela alguns dos dados - nome, idade e filiação presentes no livro de matrículas de 1924 (diurno). 


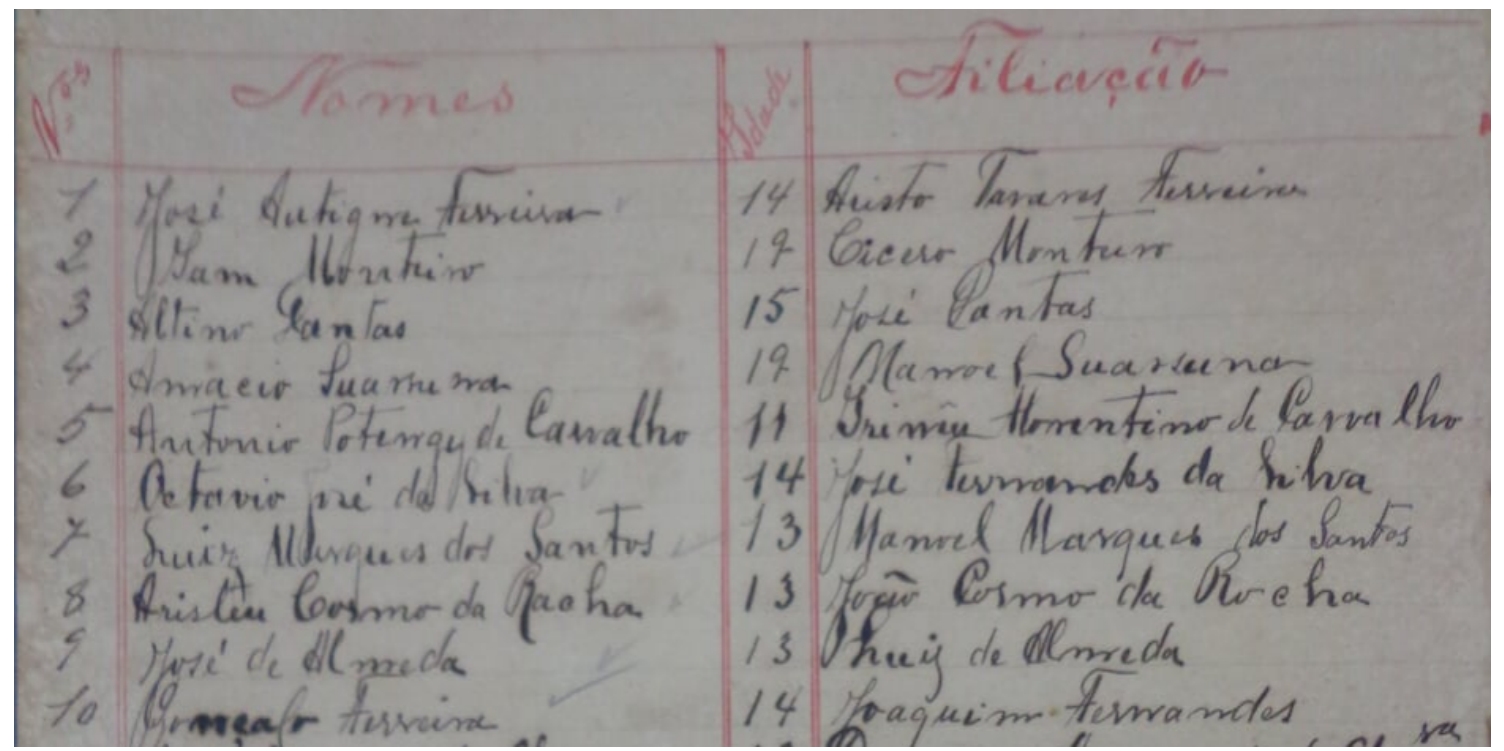

Figura 3 - Dados (nome, idade e filiação) dos aprendizes contidos no livro de matrículas de 1924 Fonte: acervo do IFRN

Em relação ao perfil dos aprendizes artífices, foram levantados e analisados registros presentes em onze livros de matrículas, compreendendo os anos de: de 1924 (diurno), 1925 (diurno), 1926 (diurno e noturno), 1927 (noturno), 1928 (diurno), 1929 (diurno), 1930 (diurno), 1931 (diurno), 1932 (diurno) e 1933 (diurno).

Nos livros de matrícula podem ser encontradas as seguintes informações: nome, filiação, idade, naturalidade, oficina, curso, além de um campo de observações, presente em alguns dos exemplares.

Outra fonte utilizada e altamente relevante foram os registros fotográficos. Neles podemos observar características do momento estudado, destacando suas peculiaridades, bem como os aspectos comportamentais da época. Nessa perspectiva, é possível dizer que a fotografia se apresenta "como um poderoso meio de representação que possibilita a construção e transmissão de uma determinada imagem de si, para si e para os outros" (CAETANO, 2007, p. 70).

\section{RESULTADOS E DISCUSSÕES}

\subsection{Os funcionários da Escola de Aprendizes Artífices de Natal}

Pelos termos de posse, foram identificados sessenta e seis funcionários que assumiram seus cargos entre os anos de 1909 e 1937. Os primeiros a ingressarem na Escola foram Sebastião Fernandes de Oliveira, nomeado diretor; Virgílio Vieira de Mello, porteiro-almoxarife, ainda em 1909; Pedro Soares de Araújo Filho, escriturário, também em 1909; Abel Juvino de Paes Barretto, professor de desenho, no ano de 1910; Maria do Carmo Torres Navarro, a única mulher entre os primeiros empossados, também em 1910; Ezechias Pegado Cortez, escriturário (ocupou lugar deixado por Pedro Soares de Araújo Filho), em 1911; e Paschoal Romano Sobrinho, Joaquim de Paula Barboza, João Viterbino Lins, José Barboza da Silva e Francisco Severo da Silva, mestres, 
respectivamente, das cinco oficinas presentes na Escola de Natal: sapataria, marcenaria, funilaria, alfaiataria e serralheria, em 1911.

A maior parte dos nomes acima elencados aparece na Figura 4, a qual representa o primeiro grupo de funcionários da Escola de Natal.

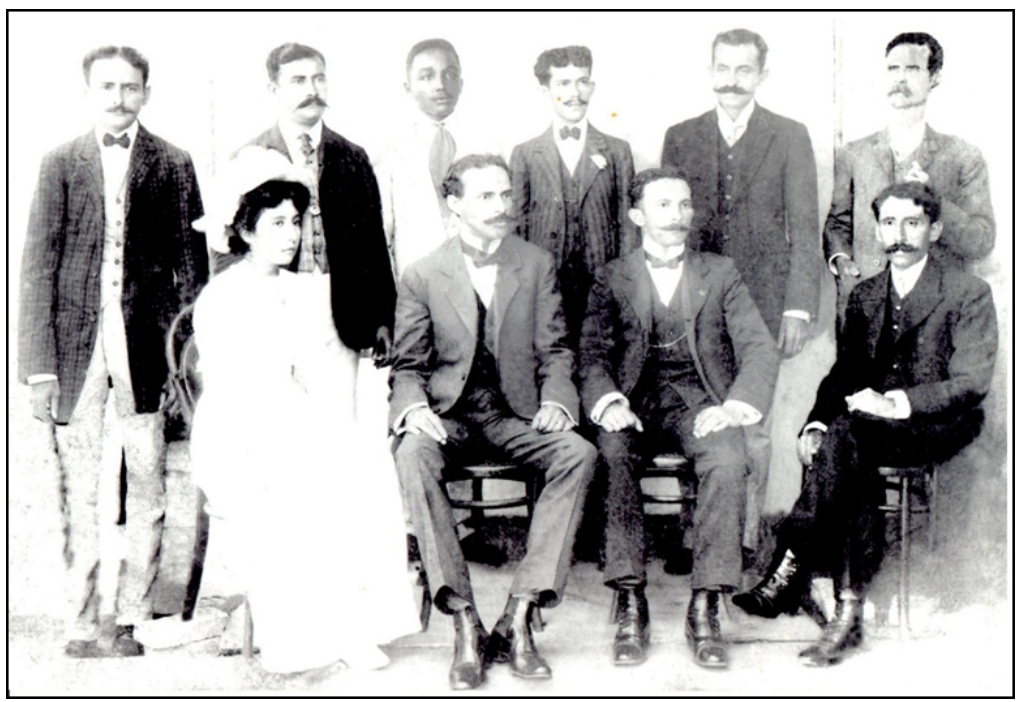

Figura 4 - Primeiros funcionários da Escola de Aprendizes Artífices de Natal, 1911 Fonte: acervo do IFRN

$\mathrm{Na}$ imagem conseguimos identificar, em pé: Abel Juvino Paes Barretto, o primeiro da esquerda para a direita; e Virgílio Vieira de Mello, o terceiro da esquerda para a direita. Sentados, estão identificados Maria do Carmo Torres Navarro, única mulher na foto; Sebastião Fernandes, ao centro; e Ezechias Pegado Cortez, terceiro da esquerda para a direita. Os homens aparecem, quase todos, engravatados; a única professora veste um vestido longo; todos aparecem elegantemente vestidos e com uma postura rígida, a qual podemos associar, simultaneamente, ao espírito da época e ao espaço ao qual estavam vinculados.

A identidade que se quer transmitir e ratificar é a da seriedade, da ordem e da disciplina típicos do espaço escolar. Os trajes dos funcionários, sua postura e posição na fotografia, com destaque para o diretor ao centro, revelam isso.

Não passa despercebido, também, o fato de haver uma única mulher presente na foto. Maria do Carmo Torres Navarro, professora do curso noturno, tomou posse na instituição em 15 de janeiro de 1910. Foi a quarta funcionária da Escola de Natal, a primeira mulher. Tinha, à época, vinte e um anos de idade e era solteira (ESCOLA, 1909-1945, s.p.). Ocupava nessa escola a única função que cabia: a de professora de primeiras letras. Viriam outras mulheres depois dela, como a sua adjunta, a professora Maria Abilgail Furtado de Mendonça, que assumiu o cargo em 1912. Também solteira, Abigail Furtado tinha, à época, dezoito anos. Ela e Maria Navarro são exceções em um universo marcadamente masculino.

Tais mulheres eram solteiras ou viúvas. Em sua tese, Rita Gurgel afirma que Maria Rosa Ribas Marinho, professora do primário, foi "exonerada do cargo por haver contraído matrimônio" (GURGEL, 2007, p. 17; grifo da autora). Segundo Guacira Louro, o trabalho para a mulher no início 
do século XX não era nada além de uma "ocupação transitória", a qual deveria ser abandonada tão logo se impusesse "a verdadeira missão feminina de esposa e mãe" (LOURO, 1997, p. 449). A afirmativa da autora torna compreensível a informação apresentada por Gurgel em relação à professora Maria Ribas. Devemos dizer, ainda, que o papel de professora é o que mais se aproxima no imaginário da sociedade de fins do XIX e início do XX ao papel que caberia ao ser feminino. A mulher-professora-mãe cuida, trata, educa, disciplina, repreende quando necessário, sem perder os traços femininos de amor e ternura que a marcariam. Essas ditas "características naturais femininas" justificaram, no período citado, a "feminização do magistério" (LOURO, 1997, p. 463).

Mas a Escola de Aprendizes era, de fato, um espaço predominantemente masculino. Exclusivamente, quando nos referimos aos alunos. Predominantemente quanto aos funcionários, como revela um rápido balanço a partir das fontes que nos ajudam a construir seu perfil, tal como é possível observar no Gráfico 1.

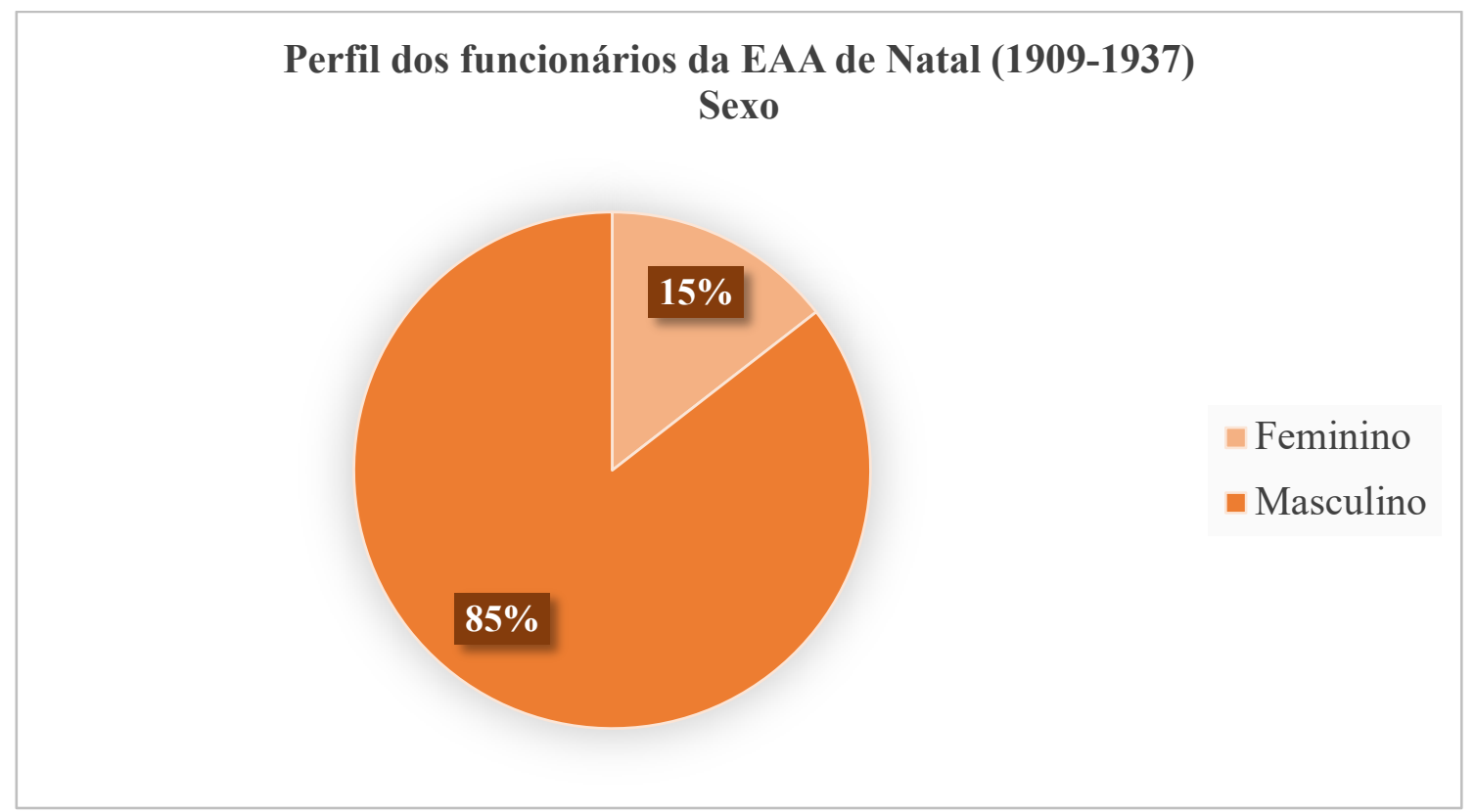

Gráfico 1 - Perfil dos servidores da Escola de Aprendizes de Natal (1909-1937), por sexo

Os termos de posse registram entrada de funcionários até o ano de 1944. Considerando os dados até esse ano, observamos o ingresso de sessenta e nove funcionários, sendo cinquenta e nove do sexo masculino $(84,3 \%)$ e onze do feminino $(15,7 \%)$. Se levarmos em conta apenas as entradas até 1937 , os números são muito próximos: cinquenta e seis homens $(84,8 \%)$ e dez mulheres (15,2\%). As mulheres são, como apontamos, professoras do primário e suas adjuntas. Odi Freire, pela que consta nos registros da Escola, foi a primeira a quebrar essa regra: era professora de Ciências físicas e naturais. Mas o ano era já o de 1943 e a Escola já passara a se chamar Liceu Industrial. 
Entre os homens, predominavam os casados, diferentemente das mulheres que deveriam ser, como dito há pouco, solteiras ou viúvas. O Gráfico 2 ajuda-nos a compreender o perfil desse funcionário.

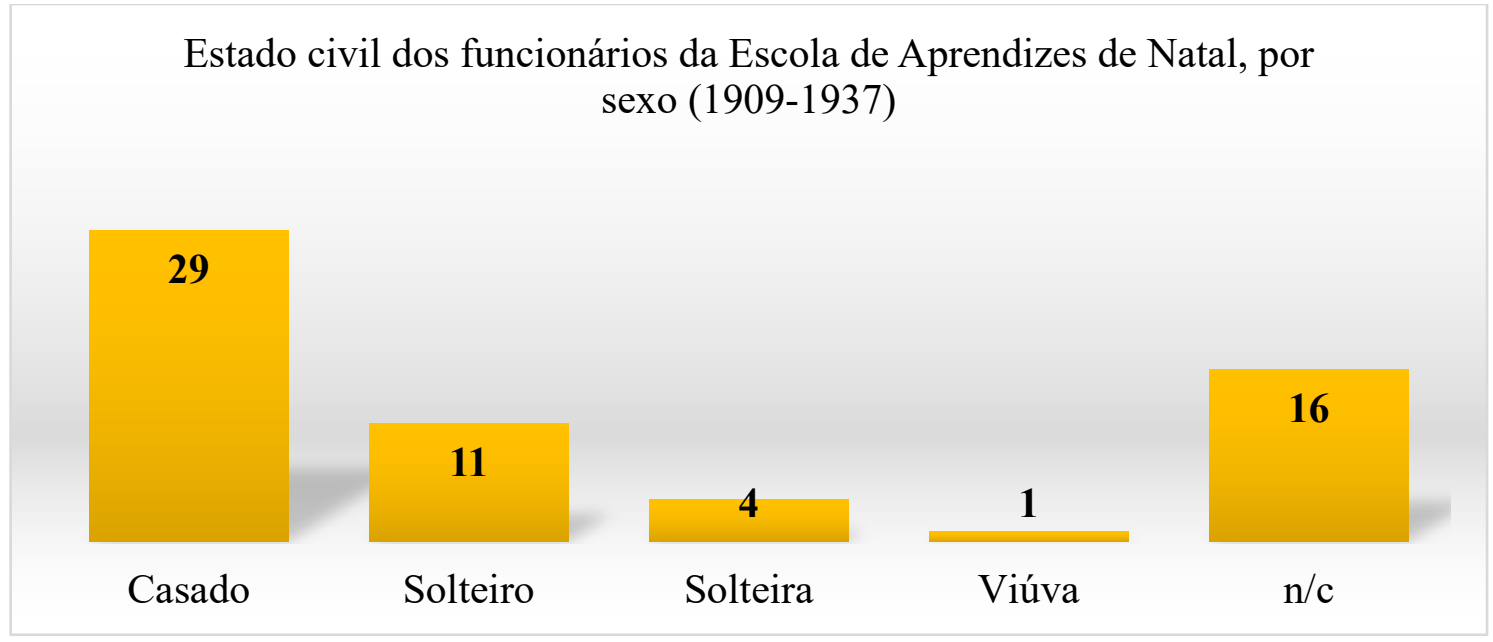

Gráfico 2 - Estado civil dos funcionários da Escola de Aprendizes de Natal, por sexo (1909-1937)

O homem casado, chefe de família, representa a clara maioria daqueles que ingressaram na Escola de Aprendizes de Natal como funcionários. Como se observa pelo gráfico, não foram identificadas, por outro lado, mulheres casadas. Eram solteiras ou, em um caso específico, o de Ruth Marinho Souto, viúva. Cabe informar que nem todos os registros de funcionários informam o estado civil; observamos dezesseis deles sem essa informação (no Gráfico 2, bem como nos demais, encontram-se representados por "n/c" - não consta). Ainda em relação ao perfil desses funcionários, verifica-se a prevalência de uma determinada faixa etária, como é exposto no Gráfico 3.

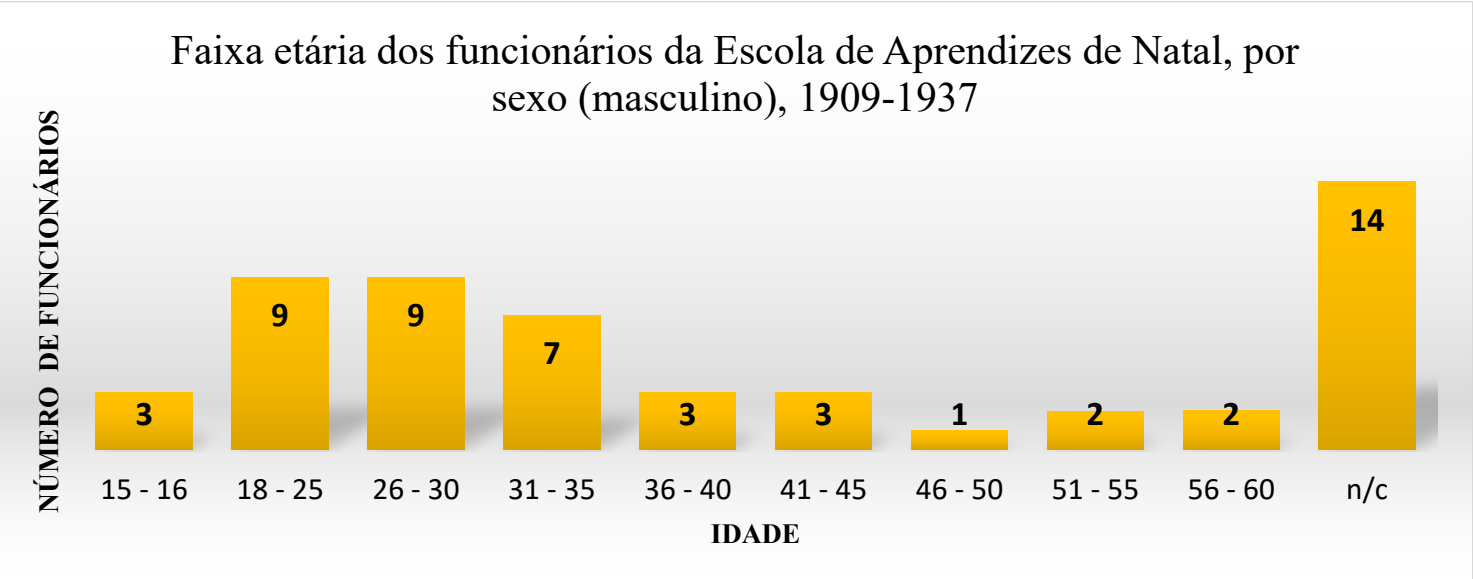

Gráfico 3 - Faixa etária dos funcionários da Escola de Aprendizes de Natal, por sexo (masculino), 1909-1937 
Entre aqueles cuja idade conseguimos identificar, pudemos verificar que a maioria tinha entre 18 e 30 anos. Entre as mulheres, o perfil etário é diferente: das cinco funcionárias cuja idade identificamos, um número de fato bem reduzido, apenas uma tinha mais de trinta anos; as demais tinham de idade no máximo 25 anos. O perfil etário reforça a ideia de que a Escola era feita por homens casados, chefes de família, e por jovens mulheres, solteiras, dedicadas a uma das poucas profissões socialmente aceitas para seu sexo, a de professora.

Diretores, escriturários, mestres, contramestres, serventes e porteiros eram todos homens. A direção da Escola, a considerarmos a mentalidade da época, era analogamente similar à da casa: tinha que ser feita por um homem, alguém de pulso firme, racional, disciplinador, com capacidade de liderar. O espaço da oficina, seus móveis, instrumentos ali utilizados, a racionalidade que se exigia do trabalho dos artífices, eram elementos que tornavam tal espaço essencialmente masculino, se tomarmos em conta o pensamento daquela sociedade. O comando dele estava nas mãos dos mestres, auxiliados pelos contramestres.

Quanto à formação dos mestres, fica claro que inicialmente os profissionais escolhidos para comandar as oficinas da Escola de Aprendizes de Natal eram homens de prática. Era o caso, por exemplo, de Paschoal Romano Sobrinho. Sapateiro, tinha sua própria fábrica - a Sapataria Romano, localizada no bairro da Ribeira - e negociava com o governo do Estado. Devemos lembrar que não havia no Brasil, no início do século XX, escolas destinadas à formação de mestres e contramestres. A Escola Normal de Artes e Ofícios Wenceslau Braz só seria inaugurada, na cidade do Rio de Janeiro, em 1918. Mas não encontramos registros de professores da Escola de Natal que tenham passado pela Escola da capital federal.

A formação desses sujeitos era eminentemente - talvez possamos dizer exclusivamente, se consideramos os primeiros anos de funcionamento das Escolas - prática. Cunha lembra que, na década de 1920, "o corpo docente das Escolas de Aprendizes Artífices foi alvo de insistentes e rigorosas críticas por parte do Serviço de Remodelação" (CUNHA, 2005, p. 80). Na sequência de sua análise do perfil dos docentes das Escolas, o mesmo autor afirma, ainda, que os mestres das oficinas "vinham diretamente das fábricas [ou do comércio e da manufatura, no caso natalense] e eram, portanto, homens sem a necessária base teórica" (Idem, ibid.).

Os relatórios ministeriais destacam essas deficiências. O ministro Lopes aponta, em 1920, a falta de habilitação dos professores para darem "aulas especiais de desenho industrial e de tecnologia" (1921, p. 451). No relatório de 1923, será a vez de Miguel Calmon du Pin e Almeida reforçar o despreparo dos mestres, ao afirmar que "o pessoal efetivo não tem habilitações suficientes para ensinar a tecnologia dos ofícios, o desenho industrial, a física e química elementares" (PIN e ALMEIDA, 1925, p. 242-243).

\subsection{Os alunos da Escola de Aprendizes Artífices de Natal}

Em maio de 1937, o jornal A Ordem, vinculado à Diocese de Natal, publicava matéria tratando da Escola de Aprendizes Artífices da capital potiguar e do seu público. O título deixava claro quem eram aqueles que frequentavam a instituição: a Escola de Aprendizes era, por excelência (dizia o autor), a Academia do Pobre. Lucio, nome daquele que assinava a matéria, afirmava que "os cursos normais, os profissionais e os superiores, continuam trancados para o pobre. É-lhe proibido sonhar sequer com um pergaminho" ("Academia". A Ordem, 18 maio 1937, 
p. 1). Ao mesmo tempo em que as portas desses espaços estavam fechadas aos desfavorecidos de fortuna, o simples aprendizado do alfabeto, o saber assinar o nome era, para ele, insuficiente ao pobre que queria vencer os desafios da vida moderna.

Lucio lembrou que, durante muito tempo, a procura por mestres em oficinas particulares foi uma saída adotada pelos jovens pobres da cidade. Citou, inclusive, as "oficinas do sr. Chico Britto" (Idem). Cabe informar que nossa pesquisa não identificou Chico Britto nos jornais. $O$ mestre, disse Lúcio, formou muitos mecânicos. Outros tantos mestres, em suas oficinas particulares, devem ter preparado igualmente vários jovens antes do surgimento da Escola de Aprendizes e mesmo após sua existência. A chegada da Escola, porém, abria um novo cenário, na medida em que a instituição era capaz de garantir, simultaneamente, o acesso às primeiras letras e a uma profissão a centenas de jovens desafortunados.

Se era significativa a contribuição da Escola para a formação do aluno, sua importância para o sustento material do aprendiz artífice não era esquecida por ele. Eis aí, segundo o autor, a singularidade da instituição: "além do ensino e do aprendizado, tem o aluno almoço e merenda, quer dizer, é uma boca a menos para a panela da família" (Idem). Família pobre, humilde, parca de recursos, o que de fato permite que apontemos que os aprendizes artífices eram, ao menos em sua maioria, desfavorecidos de fortuna. Sua permanência na instituição dependia desse sustento material. Destinada, essencialmente, a esse público, a Escola estava fadada a se tornar, segundo Lúcio, a Academia do Pobre (Idem).

Através do projeto de pesquisa intitulado Análise do perfil de aprendizes e servidores da Escola de Aprendizes de Natal: 1909-1937, apoiado pela Pró-reitora de Pesquisa e Inovação (Propi) do IFRN, pôde-se levantar e analisar 1418 registros de matrículas presentes em livros dos anos de 1924 (diurno), 1925 (diurno), 1926 (diurno e noturno), 1927 (noturno), 1928 (diurno), 1929 (diurno), 1930 (diurno), 1931 (diurno), 1932 (diurno), 1933 (diurno), e 1937 (diurno). Esses livros de matrícula trazem nome completo dos alunos, filiação, idade, endereço (na maioria dos exemplares) e, em alguns casos, profissão do responsável ou do próprio aprendiz.

Pela leitura de tais fontes, pode-se perceber, por exemplo, as preferências dos alunos quanto aos cursos oferecidos, como se vê na Tabela 1.

Tabela 1 - Distribuição dos aprendizes quanto à oficina escolhida.

\begin{tabular}{|c|ccccccc}
\hline Ano & Alfaiataria & Marcenaria & Serralheria & Funilaria & Sapataria & N/C & Total \\
\hline 1926 & 48 & 133 & 64 & 2 & 11 & 40 & 298 \\
\hline 1928 & 48 & 83 & 56 & 0 & 10 & 0 & 197 \\
\hline 1929 & 26 & 42 & 38 & 6 & 8 & 0 & 120 \\
1930 & 37 & 40 & 35 & 4 & 10 & 1 & 127 \\
1931 & 31 & 90 & 65 & 2 & 15 & 0 & 203 \\
1932 & 35 & 100 & 46 & 0 & 28 & 2 & 211 \\
\hline
\end{tabular}




\begin{tabular}{c|ccccccc|}
1933 & 55 & 95 & 57 & 0 & 31 & 3 & 241 \\
$\begin{array}{c}\text { Total } \\
\text { por } \\
\text { curso }\end{array}$ & 280 & 583 & 361 & 14 & 113 & 46 & 1397 \\
\hline
\end{tabular}

A Tabela 1 deixa claro que os aprendizes tinham preferência pelos cursos de marcenaria, sempre o mais escolhido nos anos analisados, e serralheria. O curso de sapataria e, em especial, o de funilaria, tinham baixíssima adesão. O fracasso deste curso está, certamente, relacionado à frágil situação da indústria local. Segundo informações de Sousa, a primeira indústria metalúrgica do Rio Grande do Norte, a qual seria capaz de absorver os aprendizes formados em funilaria, surgiria apenas em 1925 (2015, p. 85). O curso de marcenaria, por outro lado, tinha caráter mais artesanal e é possível supor que permitisse ao aprendiz uma inserção mais rápida no mundo do trabalho, podendo talvez realizar pequenos serviços em comércios ou residências.

Outra questão que pode ser feita a partir da análise dos livros de matrículas é de que espaços da cidade vinham os aprendizes. Essa questão, em parte respondida na Tabela 2 que se segue, ajuda-nos a delinear, a partir do conhecimento da geografia urbana de Natal no início do século XX, o perfil socioeconômico dos aprendizes.

Tabela 2 - Distribuição espacial dos aprendizes por bairros de Natal/RN e ano.

\begin{tabular}{l|ccccc}
\hline \multicolumn{1}{c|}{ Ano } & Cidade Alta & $\begin{array}{l}\text { Ribeira } \\
\text { (Rocas) }\end{array}$ & Cidade Nova & Alecrim & $\begin{array}{l}\text { Outras } \\
\text { localidades }\end{array}$ \\
$\begin{array}{l}1925 \\
\text { (Diurno) } \\
1926 \\
\text { (Diurno) }\end{array}$ & 40 & $16(5)$ & 28 & 28 & 14 \\
$\begin{array}{l}1927 \\
\text { (Noturno) }\end{array}$ & 75 & $24(13)$ & 57 & 51 & 39 \\
$\begin{array}{l}1928 \\
\text { (Diurno) }\end{array}$ & 13 & $3(2)$ & 2 & 3 & 6 \\
$\begin{array}{l}1930 \\
\text { (Diurno) }\end{array}$ & 61 & $16(12)$ & 27 & 80 & 56 \\
$\begin{array}{l}1931 \\
\text { (Diurno) }\end{array}$ & 68 & $60(50)$ & 31 & 149 & 52 \\
$\begin{array}{l}1937 \\
\text { (Diurno) }\end{array}$ & 43 & $18(17)$ & 34 & 129 & 74 \\
$\begin{array}{l}\text { Total por } \\
\text { bairro }\end{array}$ & 310 & $143(104)$ & 180 & 456 & 250 \\
\hline
\end{tabular}


A análise da Tabela 2 passa pela compreensão da geografia da cidade de Natal no início do século XX. Até década de 1930, a capital potiguar possuía quatro bairros oficiais: Cidade Alta, Ribeira (estes os mais antigos), Cidade Nova, primeiro bairro planejado, e o Alecrim, oficialmente estabelecido como bairro por resolução municipal de 1911.

A Tabela 2 mostra-nos que os jovens desafortunados que ingressaram na Escola de Natal vinham de todos os cantos da cidade. Mas é perceptível o predomínio daqueles oriundos do bairro popular do Alecrim: são 456 de um total de 1339 cuja localização é apresentada nos livros de matrícula, ou seja, pouco mais de $34 \%$ do total, número bastante significativo. E o que se pode dizer sobre eles?

O bairro do Alecrim, originalmente habitado pelas classes populares e pensado no zoning proposto pelo arquiteto Greco-italiano Giacomo Palumbo como bairro operário da cidade, era essencialmente formado por aqueles que a lei denominava de desfavorecidos de fortuna. Localizados na periferia da área urbana, eram esses aprendizes do Alecrim os que mais caminhavam até chegar à Escola. Boa parte deles, quarenta ao todo, vinham da Avenida 10, e tinham que percorrer cerca de dois quilômetros até a Escola, tendo em vista que dificilmente teriam condições de arcar com a entrada do bonde. Esses dados demonstram que a Escola de Natal era formada, em sua grande maioria, por desfavorecidos de fortuna. Os aprendizes do Alecrim, é certo, faziam parte desse público.

Poder-se-ia pensar, por outro lado, que havia tantos outros aprendizes que vinham de Cidade Nova. Mas este bairro, planejado pela e para a elite local, era também, para desprazer desse grupo social, habitado por desfavorecidos de fortuna. Isso porque referimo-nos aqui a uma cidade pequena, com centro urbano de dimensões acanhadas e transporte público precário. 0 bonde chegava apenas aos principais pontos da cidade. A população mais humilde não tinha como viver longe do centro. Ademais, antes de a região de Cidade Nova ser pensada como o aprazível bairro de Natal, já havia ali pessoas de origem humilde habitando casinholas e ranchos ("Governo Municipal", A Republica, 14 jan. 1905, p. 1).

Apesar disso, chama-nos a atenção o fato de os pais dos alunos Laert Estevam Villela, Moyses Pompeu, Antonio Ferreira, João Barbosa da Silva, Sebastião Cardozo, Raimundo Nonato Lourenço e Severino Freire, todos matriculados na Escola no ano de 1926, terem indicado como endereço residencial a Solidão, região em que ficava o sítio homônimo de propriedade de Pedro Velho de Albuquerque Maranhão. Além deles, os aprendizes João de Oliveira e José Miguel, matriculados no ano anterior, moravam, segundo seus pais, no entorno da Praça Pedro Velho, square que era o ponto central do bairro Cidade Nova. Embora não tenhamos informações precisas sobre o "bota abaixo" (Idem) que a Intendência empreendeu naquela região na busca por higienizá-la e retirar dali os pobres, acreditamos que essa ação tenha se iniciado justamente nas áreas próximas às propriedades da família Albuquerque Maranhão, a qual dominava a política local no início do século XX. Nessa perspectiva, é possível supor que alguns dos aprendizes acima referidos - uma minoria quando levamos em conta que foram identificados trezentos e dez registros de aprendizes oriundos do bairro - não se enquadravam no perfil de desfavorecidos de fortuna.

Os alunos que vinham da Cidade Alta não sofriam com o deslocamento como aqueles do Alecrim. Viviam já nas redondezas da Escola e representavam pouco mais de $21 \%$ do total de 
matrículas identificadas. Vale lembrar que a Escola se localizou sempre, ao longo do período estudado, no bairro de Cidade Alta: primeiramente na rua Presidente Passos, no antigo Hospital da Caridade; em seguida, provisoriamente na sede do Natal Club, na avenida Rio Branco; e, por fim, em prédio próprio na mesma avenida. Esses aprendizes de Cidade Alta viviam no centro de poder da capital. O espaço que estava destinado a eles era aquele que, na visão da elite, poderia transformá-los em cidadãos úteis, capazes de compreender e aceitar cordialmente a ordem daquela sociedade.

Do bairro da Ribeira, vinha um número de aprendizes que não pode ser desconsiderado: cerca de $10,7 \%$ do total. Pelos registros identificados, era o bairro de onde vinha menor número de aprendizes, certamente por ser, no início do século XX, essencialmente comercial. Mas desses alunos vindos da Ribeira, um número superior a $73 \%$ era da região das Rocas, a mais pobre da cidade e mais esquecida pelo poder público, de acordo com fontes pesquisadas. Dali, não vinha certamente outro público que não fosse o de desfavorecidos de fortuna.

Em linhas gerais, observa-se que a breve análise dos locais de residência dos aprendizes indica que a Escola de Natal era frequentada, em essência, por jovens desafortunados. O Alecrim, bairro popular, era o local de onde vinha a maioria dos alunos. A Cidade Nova, por outro lado, era local de origem de uma minoria. Dos que vinham da Ribeira, grande parte morava na paupérrima região das Rocas. Há determinadas localizações, porém, que parecem insistir em mostrar que havia exceções, as quais surgem, de qualquer modo, mais para confirmar a regra do que para negá-la.

Em relação a evasão escolar, do período estudado, é certo que a Escola, enquanto instituição educativa, é um espaço disciplinar. Se Foucault (2009) ajuda-nos a entender os fatores que contribuem para o surgimento desse poder disciplinar, Hobsbawn (2002), seguindo outra linha interpretativa, explica-nos como a Escola exerce uma disciplina sobre os alunos ao "estabelecer padrões comuns de comportamentos e valores". Afonso (2009), em sua tese de doutoramento, entende que a educação significa "desenvolver o sentido dos valores, os modos de pensar e os esquemas comportamentais". Esses comportamentos e valores referidos por ambos os autores são aqueles vinculados aos grupos que promovem a Escola como espaço de transformação.

Relativamente às Escolas de Aprendizes, o grupo social que dirigia a República brasileira, a elite, foi a sua criadora e promotora. Eram, portanto, seus comportamentos e valores que desejavam ver reproduzidos nessas Escolas. Em essência, elas deveriam ser espaços para disciplinar, transformar aqueles jovens desafortunados para que, de maneira aparentemente contraditória, a sociedade permanecesse a mesma dos tempos do escravismo.

As Escolas de Aprendizes recebiam jovens que viviam à margem daquela sociedade do início do século $X X$, esquecidos pela República. Mas mesmo com as mudanças vivenciadas ao longo do período estudado, especialmente a partir da década de 1920, essas Escolas se mostraram incapazes de integrar esse público, predominantemente formado pelos desfavorecidos de fortuna, às suas realidades. Dito de outro modo, as Escolas a que nos referimos foram transformadas por um processo que as normatizou e racionalizou, com ênfase na padronização curricular que visava a formação de um profissional mais prático. Mas elas continuaram a ter imensa dificuldade em integrar o elemento humano, o que se reflete nos altos índices de evasão. 
Esse processo de normatização das Escolas de Aprendizes procurou estabelecer a ordem onde, supostamente, havia desordem. Desejou, por exemplo, estabelecer a cultura do trabalho onde haveria um estado natural tendente à vadiagem e ao mundo dos vícios e crimes. Esse discurso é falacioso, mas se apresenta como verdadeiro e inquestionável. Além disso, a escola como instituição - recém-inventada: a escola moderna é um fenômeno da segunda metade do século XIX - é essencialmente negentrópica, pois, com seu fazer busca negar a entropia, o estado natural das coisas, ao querer criar uma ordem regular - um espaço específico, um currículo, uma hierarquia de funções, um ensino seriado, a disciplina escolar - a qual é desconhecida pelos alunos e que se procura impor sobre eles.

O que foi observado, porém, é que há um outro lado que também tem seus valores e comportamentos - como FRAGO (1995) observa, tratam-se de seres humanos e não materiais inorgânicos - e que não aceita sempre de maneira cordial a ordem que se the procura impor. Por isso, essa disciplina a que nos referimos, presente nos documentos analisados neste artigo, não pode ser vista como algo sufocante e intransponível. Ela é constantemente testada e transposta pelos aprendizes artífices, mesmo que isso signifique, em muitas situações, sua eliminação da Escola.

Tendo partido, especialmente, dos relatórios do Ministério da Agricultura, Indústria e Comércio e dos livros de matrícula, mapeamos os índices de evasão da Escola de Natal em diversos anos do recorte temporal analisado. Os dados presentes na Tabela 3 abaixo merecem nossa atenção.

$\begin{array}{cc}\begin{array}{c}\text { Tabela 3 }- \text { Número de alunos eliminados/evadidos entre } 1913 \text { e } 1937 \\ \text { NÚMERO DE }\end{array} \\ \begin{array}{c}\text { PORCENTAGEM DE } \\ \text { ELIMINADOS/EVADIDOS }\end{array} \\ 47 & 39,16 \\ 35 & 29,16 \\ 35 & 23,64 \\ 53 & 43,08 \\ 1 & 0,57 \\ 36 & 23,84 \\ 14 & 7,56 \\ 17 & 8,37 \\ 28 & 10,44 \\ 66 & 33,33 \\ 54 & 25,59 \\ 46 & 19,00 \\ 134 & 44,66 \\ 27 & 12,40 \\ 28 & 10,83\end{array}$

Sobre a Tabela 3, os dados dos anos de 1924 a 1932, e 1937 foram retirados dos livros de matrícula. O dado relativo ao ano de 1935 foi retirado da Sinopse estatística do Estado (1939). Por 
fim, os dados referentes ao ano de 1936 foram retirados de Cunha (2005, p. 107), pois não foram encontrados na Sinopse estatística, fonte usada por esse autor, qualquer referência ao índice de evasão nesse ano.

A Tabela 3 nos mostra que os índices de evasão na Escola foram sempre altos ao longo do período estudado. Os livros de matrículas, por sua vez, revelam que a evasão atingiu todos os cursos da Escola de Aprendizes de Natal, como se verifica na Tabela 4.

Tabela 4 - Número de evadidos por curso/oficina

\begin{tabular}{l|lllllll} 
Ano & Alfaiataria & Marcenaria & Serralheria & Funilaria & Sapataria & N/C & TOTAL \\
1926 & 0 & 7 & 5 & 0 & 1 & 1 & 14 \\
1928 & 0 & 0 & 0 & 0 & 0 & 0 & 0 \\
1929 & 0 & 0 & 0 & 0 & 0 & 0 & 0 \\
1930 & 1 & 1 & 4 & 0 & 1 & 0 & 7 \\
1931 & 6 & 37 & 24 & 1 & 4 & 0 & 72 \\
1932 & 4 & 21 & 12 & 0 & 6 & 0 & 43 \\
1933 & 2 & 4 & 5 & 0 & 3 & 0 & 14 \\
Total & 13 & 70 & 50 & 1 & 15 & 1 & 150
\end{tabular}

O maior número de evadidos pertencia ao curso de Marcenaria. No curso de funilaria, por outro lado, identificamos um único evadido. A distância entre os números não deve, porém, causar espanto. Como vimos na Tabela 1, o curso de Marcenaria era o preferido pelos jovens aprendizes, ao passo que o de funilaria recebia um reduzidíssimo número de alunos. Em termos proporcionais, o número de evadidos era, portanto, muito próximo nos cinco cursos oferecidos pela Escola de Natal.

Quanto aos anos apresentados na Tabela 3, os que mais se destacam são os de 1917 e 1935. Este ano destoa dos demais da década de 1930 que, em geral, apresenta índices de evasão mais baixos. O que teria acontecido na Escola de Natal em 1935 para que a evasão tenha chegado perto dos $45 \%$ ? As fontes não trazem causas específicas que ajudem a explicar esse fenômeno, mas nossa hipótese é de que a Intentona Comunista de 1935 tenha relação com esse alto índice. É possível que alguns alunos tenham seguido o caminho de um ex-aprendiz, Lindolpho Montenegro, que se associou ao movimento, e, por conseguinte, tenham sido expulsos da Escola. Essa hipótese é plausível, tendo em vista que não há fatores internos evidentes que possam ter contribuído para essa súbita alta no índice de evadidos. 


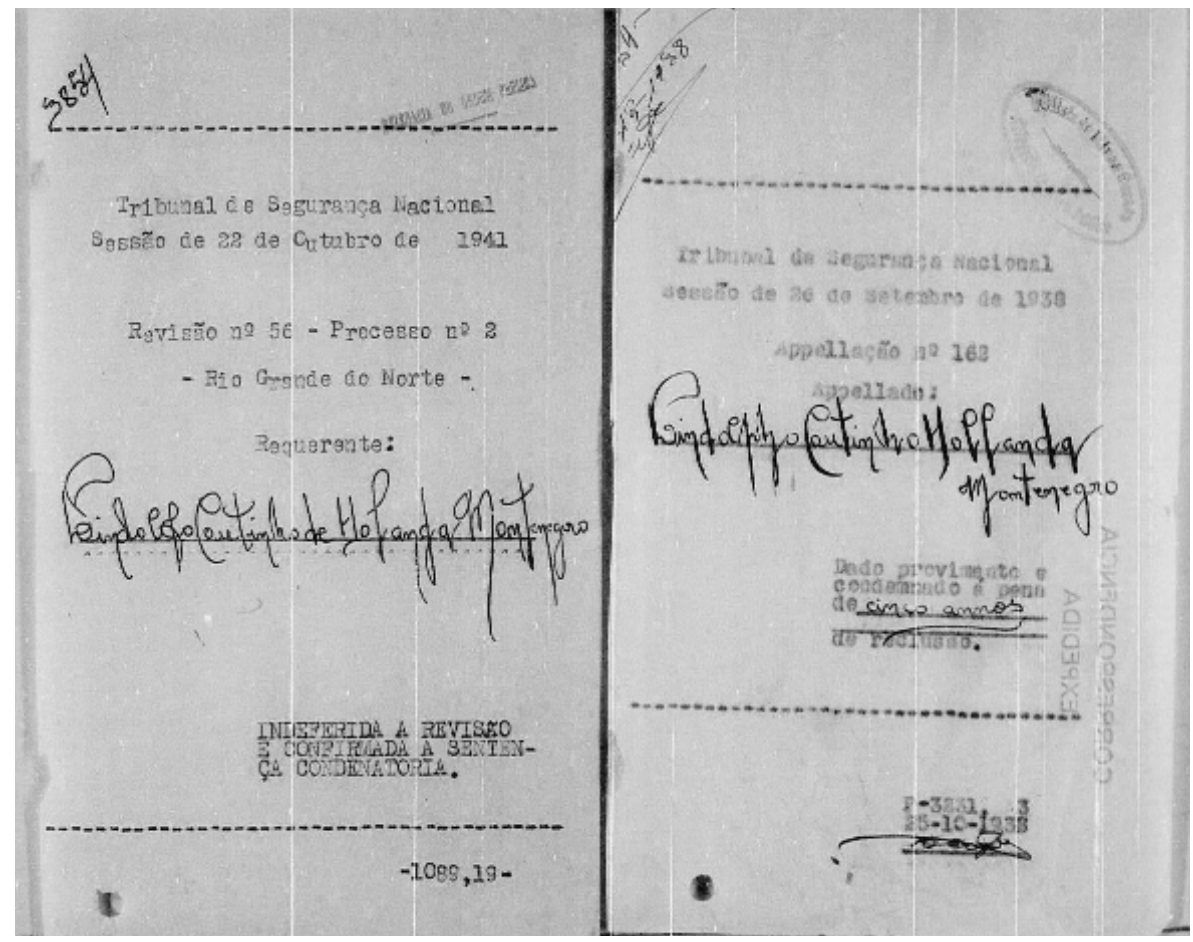

Figura 5: registro de processo judicial que teve como réu Lindolpho C. de Hollanda Montenegro², o ex-aluno da Escola. Fonte: Sistema Integrado de acesso ao Arquivo Público Mineiro (http:// www.siaapm.cultura.mg.gov.br/)

Quanto ao ano de 1917, a causa do elevado índice de evasão parece ser mais clara. Em um relatório ministerial do ano de 1916 pode-se ver que no ano anterior as diárias pagas aos aprendizes, elemento fundamental para sua permanência, foram suspensas pelo Congresso, o que fez com que as Caixas de mutualidade, destinadas à assistência aos alunos, passassem a funcionar com significativas dificuldades (CAVALCANTI, 1916). Em relatório referente ao ano de 1917, Silvino Bezerra Neto apontava que ainda não havia sido "reestabelecida a verba destinada ao pagamento das diárias dos alunos, que mantinham prósperas as Cooperativas, concorrendo, igualmente para a elevação das matrículas" (BEZERRA NETO, 1918), situação que preocupava o diretor da Escola, posto que gerava reflexos diretos no número de matrícula e também no de evadidos.

O ano de 1919 pode parecer, à primeira vista, atípico. A Tabela 3 indica a evasão de apenas um aluno. A Escola teria conseguido conter a evasão naquele ano? Certamente, não é o caso. Não encontramos o livro de matrículas de 1919 e o relatório ministerial deste ano é bastante impreciso ao tratar da evasão na Escola. Não traz números gerais, limitando-se a apontar um único caso: "deu-se a eliminação de 1 aprendiz responsável pelo desvio de artefatos e matérias-primas da oficina de marcenaria" (LOPES, 1920, p. 339). É bastante provável que dezenas de outros alunos tenham sido eliminados naquele ano, mas apenas um aprendiz, não denominado, é referido no relatório. Também não sabemos de sua idade, seu local de residência, ou que ano cursava na Escola. Mas podemos observar que a disciplina escolar era rígida. E contraditória: a Escola que prometia reformar jovens que tendiam, de acordo com o discurso da elite, à vagabundagem e ao

\footnotetext{
${ }^{2}$ O ex-aluno foi condenado pelo Tribunal de Segurança Nacional (TSN) em 1938 e teve sentença ratificada em 1941, como se verifica no Sistema Integrado de acesso ao Arquivo Público Mineiro (http:// www.siaapm.cultura.mg.gov.br/)
} 
mundo dos crimes, expulsou sumariamente um jovem por ter desviado materiais da oficina de marcenaria.

O aluno não denominado é também uma exceção pelo fato de a razão de sua expulsão ter sido clara. Em vários outros casos não foi possível identificar o motivo que levou o aprendiz a deixar a Escola. Citamos, por exemplo, o caso de Edivandi Romano. O que teria se passado com o filho de Paschoal Romano, fiscal da municipalidade? É difícil saber, pois seu nome aparece apenas riscado. O mesmo se passou com outras dezenas de aprendizes: apenas tiveram seus nomes riscados e, algumas das vezes, outros nomes foram sobrepostos, como observamos na Figura 5.

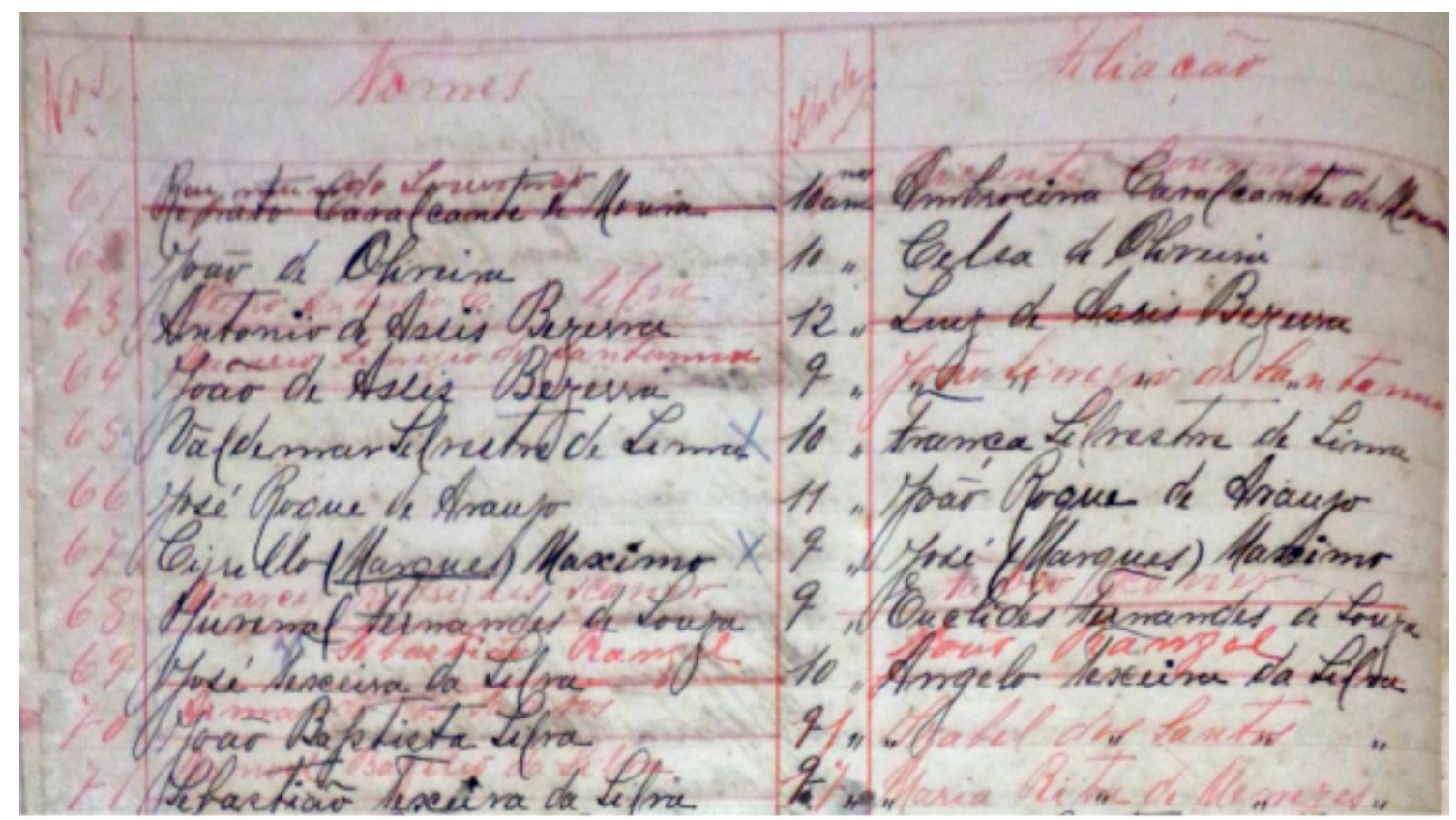

Figura 5 - Página do livro de matrículas do ano de 1925 (diurno). Fonte: acervo do IFRN

É certo que tais aprendizes deixaram a Escola, pois seus nomes não voltam a figurar nos livros de matrícula. Mas o que teria se passado com eles? Teriam abandonado a Escola, ou sido expulsos por questões disciplinares? É possível que esses alunos tenham excedido o número limite de 30 faltas não justificadas, estabelecido nos regulamentos de 1911 e 1918. Apenas no ano de 1933, identificamos catorze alunos que excederam esse número e acabaram por ser desligados da Escola. Foi o que se passou com o aluno Antônio Freira da Costa, por exemplo, visto na Figura 6. 


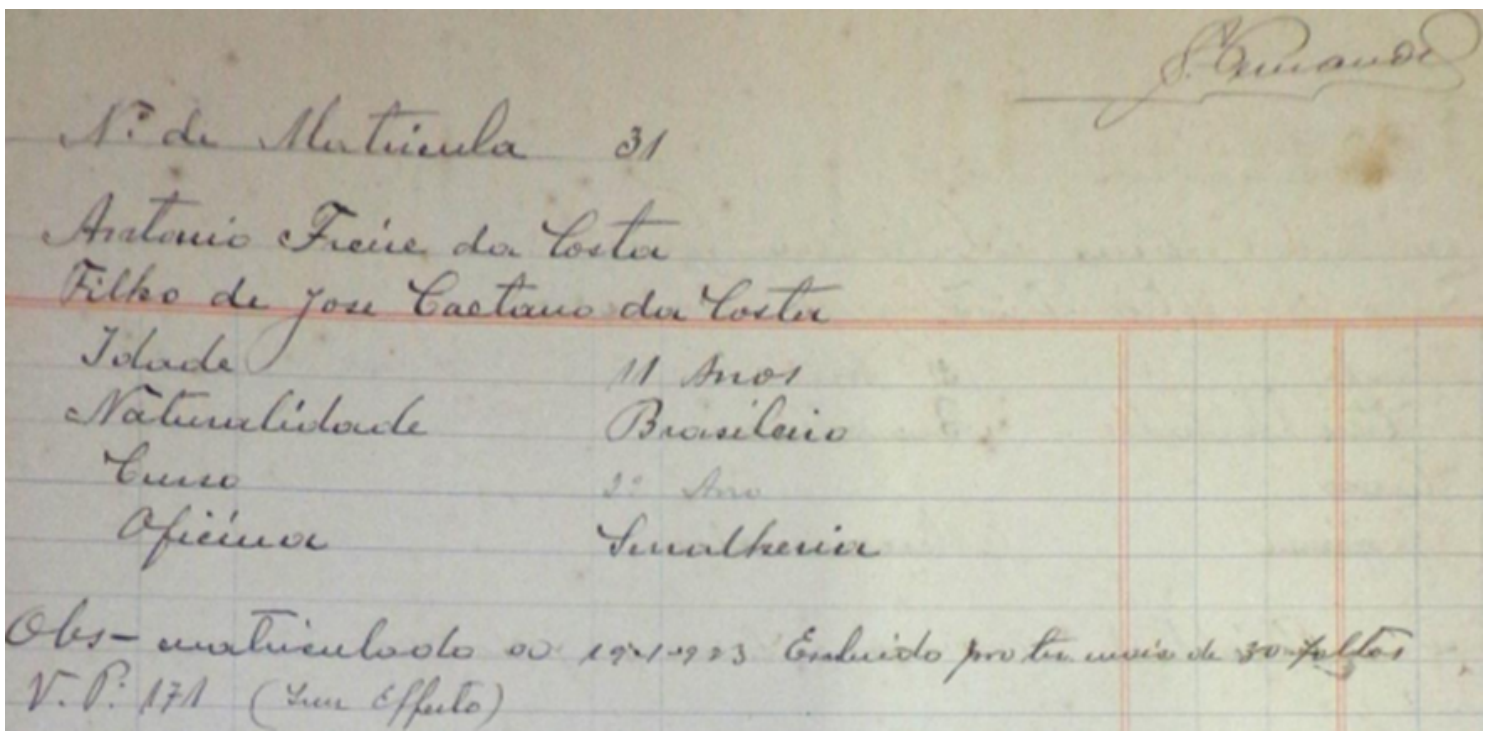

Figura 6 - página do livro de matrículas de 1933, com registro do aprendiz Antonio Freire da Costa Fonte: acervo do IFRN

No registro acima, assinado pelo escriturário da Escola, vemos que Antonio Freire da Costa tinha 11 anos e estava no 20 ano do curso de Serralheria. É possível que Antonio não tenha se acostumado com o trabalho na oficina. Hipótese menos provável é a de que não tenha se adaptado ao curso, posto que nestes casos uma transferência era um caminho mais comum. Parece-nos mais razoável supor que tenha deixado a Escola para ajudar seu pai, José Caetano da Costa, no sustento da família.

Outros tantos aprendizes foram punidos por questões disciplinares. Foi o que se passou com Altino Dantas, Leonel R. da Silva e Manoel do Nascimento, no ano letivo de 1924 (ESCOLA, 1924), e Antonio Amaral, em 1933 (ESCOLA, 1933). Esses sujeitos - eliminados a bem da ordem, da decência, da moral ou da disciplina - não se enquadraram ao rigor disciplinar da Escola de Natal.

Os altos índices de evasão, é certo, não se ligavam apenas a questões disciplinares. Como aponta Cunha (2005, p. 109-110) há também questões materiais relevantes que justificavam a saída de aprendizes que, muitas das vezes, precisavam contribuir para o sustento material de suas famílias. Outros vinham do interior e podiam ter sérias dificuldades para se manter na capital. No livro de matrículas de 1937, vemos que um aluno não identificado "saiu por falta de recursos" (ESCOLA, 1937). Nesse mesmo ano, trinta e um alunos saíram da Escola por terem mudado de residência; trinta deles foram (ou retornaram) para o interior do estado. Desafortunados que, certamente, não encontraram sustento material na capital.

Fosse por questões disciplinares ou materiais, muitos alunos deixaram a Escola de Aprendizes de Natal. Por conseguinte, o número de concluintes era bastante reduzido. Cunha aponta que no período de 1913 a 1917 a taxa de conclusão ficou em 4,1\%; no período de 1917 a 1920, não passou de $2.4 \%$ (2005, p. 109). A Tabela 5 mostra o número de concluintes em alguns anos das décadas de 1910 e 1920. 
Tabela 5 - número de concluintes por ano na escola de aprendizes de natal

ANO

1916

Número de concluintes

1917

1919

1920

1922

1923

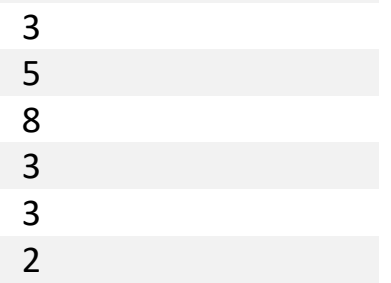

Embora os dados sejam escassos, é possível verificar através deles que o número de aprendizes que saíram diplomados da Escola de Natal foi, ao menos durante boa parte do período estudado, bastante reduzido. Em sua tese, Francisco Carlos de Sousa informa que apenas quarenta e nove alunos se formaram entre 1913 e 1942, ou seja, cerca de 0,79\% do total de matriculados (SOUSA, 2015, p. 230). Esses dados poderiam nos levar a definir que a experiência da Escola de Aprendizes de Natal - não muito distante da vivenciada pelas demais escolas do gênero - resultou em um estrondoso fracasso. Essa avaliação seria, porém, temerária.

Ao longo de vinte e sete anos, é possível estimar que mais de cinco mil alunos frequentaram a Escola de Aprendizes Artífices de Natal. É fato que muitos não concluíram seus cursos, mas não se pode negar, igualmente, que o tempo vivido na Escola transformou de alguma maneira a trajetória daqueles sujeitos. Sujeitos que foram trabalhar na indústria, no comércio, na própria escola onde se formaram, ou que se envolveram no levante comunista de 1935. Sujeitos, enfim, que lidaram com a ordem e disciplina do espaço escolar, mas que também resistiram, em ocasiões diversas, a essa mesma ordem e disciplina.

\section{CONSIDERAÇÕES FINAIS}

Ao longo da pesquisa, foram mapeados centenas de alunos, alcançando um total de 1418 registros. Analisamos, ainda, o perfil de dezenas de funcionários que fizeram parte dessa Escola, entre os anos de 1909 e 1937. Estes dados ajudam-nos a compreender com mais clareza o perfil da clientela que ingressou na referida instituição no período informado, bem como o dos funcionários que a formaram, elementos pouco abordados em outros trabalhos referentes à temática abordada no projeto.

Foram coletados dados de 75 servidores (mestres, contramestres, professores e diretores) que fizeram parte da Escola de Aprendizes Artífices de Natal, entre os anos de 1909 e 1937. Parte dessas informações já foi lançada em banco de dados na World Wide Web (WWW). As informações ainda não alocadas na Web, estão presentes em planilhas do Excel e gráficos, que permitem uma rápida visualização dos resultados da pesquisa. Em linhas gerais, pudemos observar que o perfil dos servidores guarda íntima relação com os valores da sociedade da época. A Escola se apresentava como um microcosmos da sociedade em que estava inserida. Ela era feita e comandada por homens. O perfil mais comum é do homem adulto, com cerca de 25 anos e casado. A mulher só conseguia se inserir nela em um papel tido como feminino: o de professora. Devia ser solteira ou viúva, pois às casadas cabia, antes de tudo, o cuidado do lar e da família. 
Outra marca singular da instituição foi a disciplina que se buscou estabelecer no espaço escolar. Diretores, mestres, professoras e demais funcionários foram, sem dúvida, agentes dessa disciplina que se procurou estabelecer sobre os aprendizes, na busca pelo modelamento de sua moral e caráter.

Em síntese, a pesquisa leva-nos à compreensão de que a Escola de Aprendizes de Natal teve como maior finalidade, ao longo do período estudado, o disciplinamento daqueles jovens denominados genericamente de desfavorecidos de fortuna. Nessa perspectiva, a formação profissional representava um meio para tal disciplinamento, e não um fim em si mesmo.

\section{REFERÊNCIAS}

AFONSO, J. A. M. M. (2009). Protestantismo e Educação: História de um projecto pedagógico alternativo em Portugal na transição do séc. XIX. Braga: Centro de Investigação em Educação (UMinho).

CAETANO, A. (2007). Práticas fotográficas, experiências identitárias: a fotografia privada nos processos de (re)construção das identidades. In Sociologia, problemas e práticas, 55, pp. 6989.

CHALHOUB, S. (2001). Trabalho, lar e botequim: o cotidiano dos trabalhadores no Rio de Janeiro belle époque. Campinas: Ed. Unicamp.

CUNHA, L. A. (2005). O ensino de ofícios nos primórdios da industrialização (2a ed.). São Paulo: Unesp.

FONSECA, C. S. da. (1986). História do ensino industrial no Brasil (2ª ed.). Rio de Janeiro: Senai.

FOUCAULT, M. (2009) Vigiar e punir: nascimento da prisão (37ạ ed.). Petrópolis: Vozes.

GURGEL, R. (2007). A trajetória da Escola de Aprendizes Artífices em Natal: República, trabalho e educação (1909-1942). Tese de doutoramento, Universidade Federal do Rio Grande do Norte, Natal, Brasil.

HOBSBAWN, E. J. E. (2002). A produção em massa de tradições. In E. J. E. Hobsbawn \& T. Ranger (Orgs.), A Invenção das tradições (3ạ ed.) (pp. 271-316). Rio de Janeiro: Paz e Terra.

LOURO, G. L. (1997). Mulheres na sala de aula. In M. del Priore (org.). História das mulheres no Brasil, 2, p. 443-481. São Paulo: Contexto.

MEDEIROS, A. L. de. (2011). A forja e a pena: Técnica e humanismo na trajetória da Escola de Aprendizes Artífices de Natal à Escola Técnica Federal do Rio Grande do Norte. Natal: Ed. IFRN.

SOUSA, F. C. O. de. (2015). Em nome da ordem e do progresso: a formação profissional no percurso da escola de aprendizes artífices à escola técnica federal do Rio Grande do Norte (1909-1971). Tese de doutorado, Universidade Federal do Rio Grande do Norte, Natal, Brasil. 
FRAGO, A. V. (1995). Historia de la educación y historia cultural: Posibilidades, problemas, cuestiones. In Revista Brasileira de Educação, 306, pp. 245-269.

\subsection{Decretos, relatórios de governo e ministeriais}

Decreto no 7.566, de 23 de setembro de 1909 (1909). Retirado de: portal.mec.gov.br/setec/arquivos/pdf3/decreto_7566_1909.pdf

CAVALCANTI, J. R. B. (s.d.). Relatório do anno de 1916, apresentado ao Presidente da Republica dos Estados Unidos do Brazil, no anno de 1916. Retirado de: http://brazil.crl.edu/bsd/bsd/u2008/

LIMA, J. G. P. (s.d.). Relatório apresentado ao Presidente da República dos Estados Unidos do Brazil pelo Ministro de Estado dos Negocios da Agricultura, Industria e Commercio, no anno de 1918. Retirado de: http://brazil.crl.edu/bsd/bsd/u2010/.

LOPES, I. L. (1920). Relatório apresentado ao presidente da República dos Estados Unidos do Brasil pelo Ministro de Estado dos Negocios da Agricultura, Industria e Commercio (1919). Rio de Janeiro: Papelaria e Typographia Villas-Boas \& C.

LOPES, I. S. (1921). Relatório apresentado ao Presidente da República dos Estados Unidos do Brazil pelo Ministro de Estado dos Negocios da Agricultura, Industria e Commercio, no anno de 1920. Retirado de: http://brazil.crl.edu/bsd/bsd/u2017/.

PIN e ALMEIDA, M. C. du (1925). Relatorio do Ministério da Agricultura, Industria e Commercio, apresentado ao presidente da República dos Estados Unidos do Brasil, anno de 1922. Rio de Janeiro: Imprensa Nacional.

Departamento Estadual de Estatística (1939). Sinopse estatística do estado, n. 3. Natal: Tipografia do SEPT.

\subsection{Matérias de periódicos}

“Governo Municipal”. (1905). A Republica, Natal, 14 jan., p. 1.

"Governo Municipal”. (1905). A Republica, Natal, 16 jan., p. 1.

LUCIO. "A Academia do Pobre". (1937) A Ordem, Natal, 18 maio, p.1. 